\title{
Introduction and selection studies at the Federal Research Centre the Subtropical Scientific Centre of the Russian Academy of Sciences
}

\author{
Alexey Ryndin, Natalia Slepchenko*, and Raisa Kulyan
}

Federal Research Centre the Subtropical Scientific Centre of the Russian Academy of Sciences, Yana Fabritsiusa str. 2/28, Sochi, 354002, Russia

\begin{abstract}
The paper deals with topical issues of biologization of introduced and selective studies, which represent new approaches to conservation and rational use of plant resources. An extensive gene pool of subtropical, flower and southern fruit crops has been mobilized at FRC SSC of RAS (Sochi). Bioresource collections include 2,650 cultivar samples, of which $20 \%$ are perennial herbaceous plants, $12 \%$ are bulbous and bulbotuberiferous, $11 \%$ are tree and shrub crops, $10 \%$ are irises, $8 \%$ are pelargoniums, $5 \%$ are citrus crops and others. Based on the collections studies, adaptive assortments have been developed for the humid subtropics of the Russian Federation, research is continuing for a number of cultures. A special place in the Centre's research is occupied by the study of the collected species of natural flora, most of which have unique, including decorative, medicinal and other properties. The collections are the basis for conducting breeding research in various areas. Over the past 10 years, 85 cultivars of flower crops have been created (including 36 pelargoniums, 13 fruit crops, 4 hazels and 1 tea plant).
\end{abstract}

Recently, much attention has been paid to the ecologization and biologization of many processes, including crop production field [1-7]. Often, these terms are understood as effective ways of using natural resources, increasing yields and sustainability mechanisms, as well as improving and restoring soil fertility, and using biological protection means. The use of biological preparations, biostimulants, low-toxic fungicides and insecticides allows us to significantly reduce the volume of chemical treatments when obtaining high yields and creating stable urban landscapes [8-13].

At first glance, biologization is mainly associated with agricultural production, but the issues of conservation and study of biodiversity are key in solving the problems of both food security and the creation of sustainable agro- and urban landscapes [12, 13].

The introduction and involvement of new sustainable facilities in green construction increases not only the efficiency of using natural plant resources, but also their

\footnotetext{
${ }^{*}$ Corresponding author: slepchenko@,vniisubtrop.ru
} 
environmental-improving, phytomeliorative and phytosanitary properties. At the present stage, a symbiosis of environmentally friendly elements of cultivation, biological means of plant protection and soil fertility improvement is used in agricultural technologies that are applied for many crops. However, special attention should be paid to the selection and allocation of a stable assortment developed and created as a result of introduction and breeding studies $[14,15]$.

Federal Research Centre the Subtropical Scientific Centre of the Russian Academy of Sciences (FRC SSC of RAS) preserves and maintains an extensive gene pool of bioresource collections, which includes 2,650 cultivar samples (Fig. 1). The issues of studying collections and identifying adaptive assortments are an important area of research [14-17].

Over the past 10 years, assortments have been developed for many crops, including cultivar samples adapted to the conditions of humid subtropics. Among subtropical crops, cultivars of oriental kaki persimmon, feijoa and kiwifruit have been studied and proposed for cultivation. Research is being conducted on the selection of peach and pear cultivars. An assortment of citrus crops for amateur citrus farming has been offered.

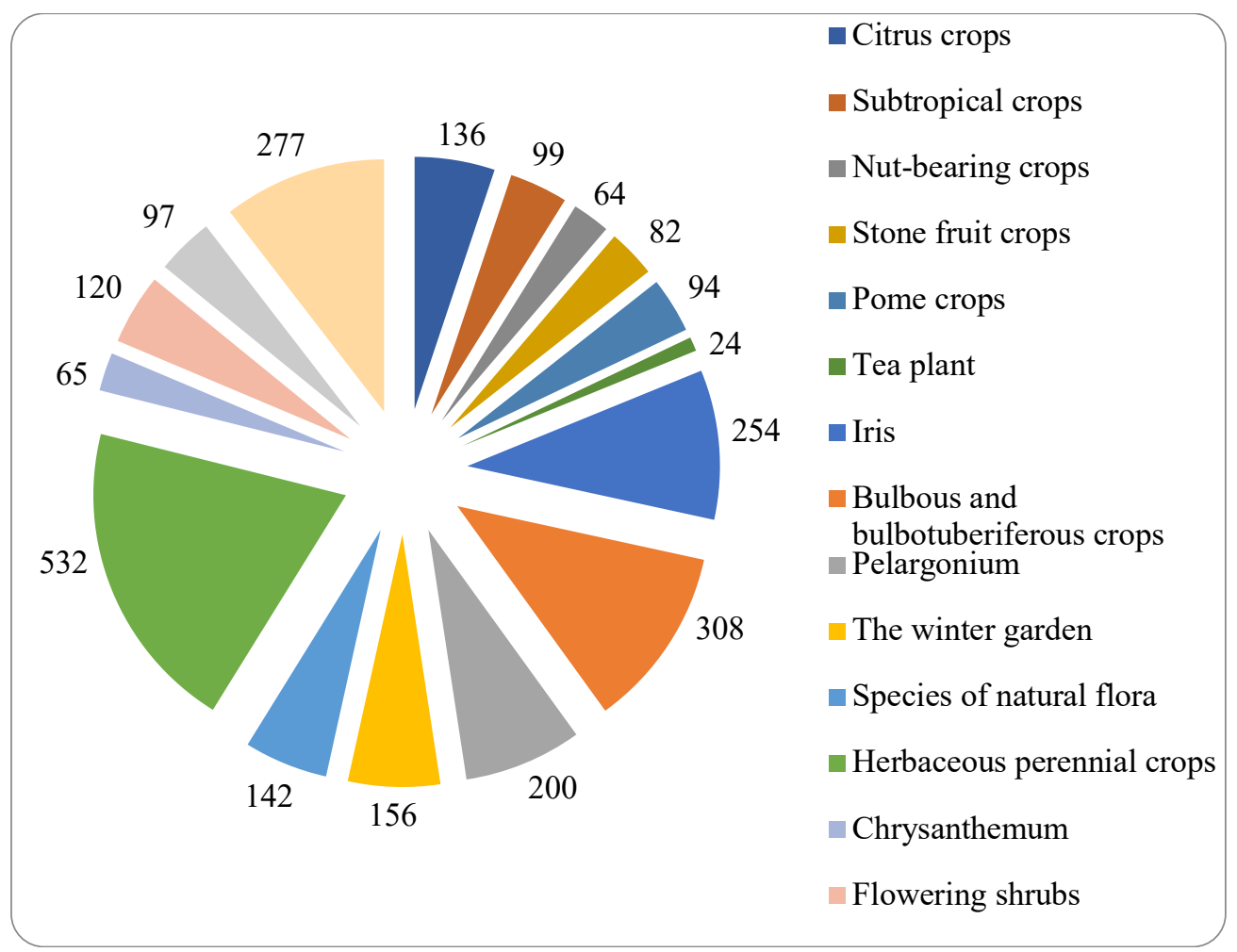

Fig. 1. Bioresource collections of FRC SSC of RAS

Currently, ornamental gardening and floriculture are actively developing in the modern world, the range of flower and ornamental crops is expanding.

FRC SSC of RAS has developed an assortment of flowering shrubs, a number of bulbous crops (tulips, daffodils) and pelargoniums. Research is continuing on collections of irises, perennial herbaceous, bulbous and bulbotuberiferous crops, roses, chrysanthemums and others.

Selective improvement of the existing assortment of subtropical, southern fruit crops is aimed at increasing productivity and resistance to abiotic and biotic stressors. Selection of 
flower crops is carried out in order to create productive, original, highly decorative and environmentally sustainable cultivars that bloom at different times. Over the past 10 years, the Centre has created more than 100 cultivars of the studied crops (Fig. 2).

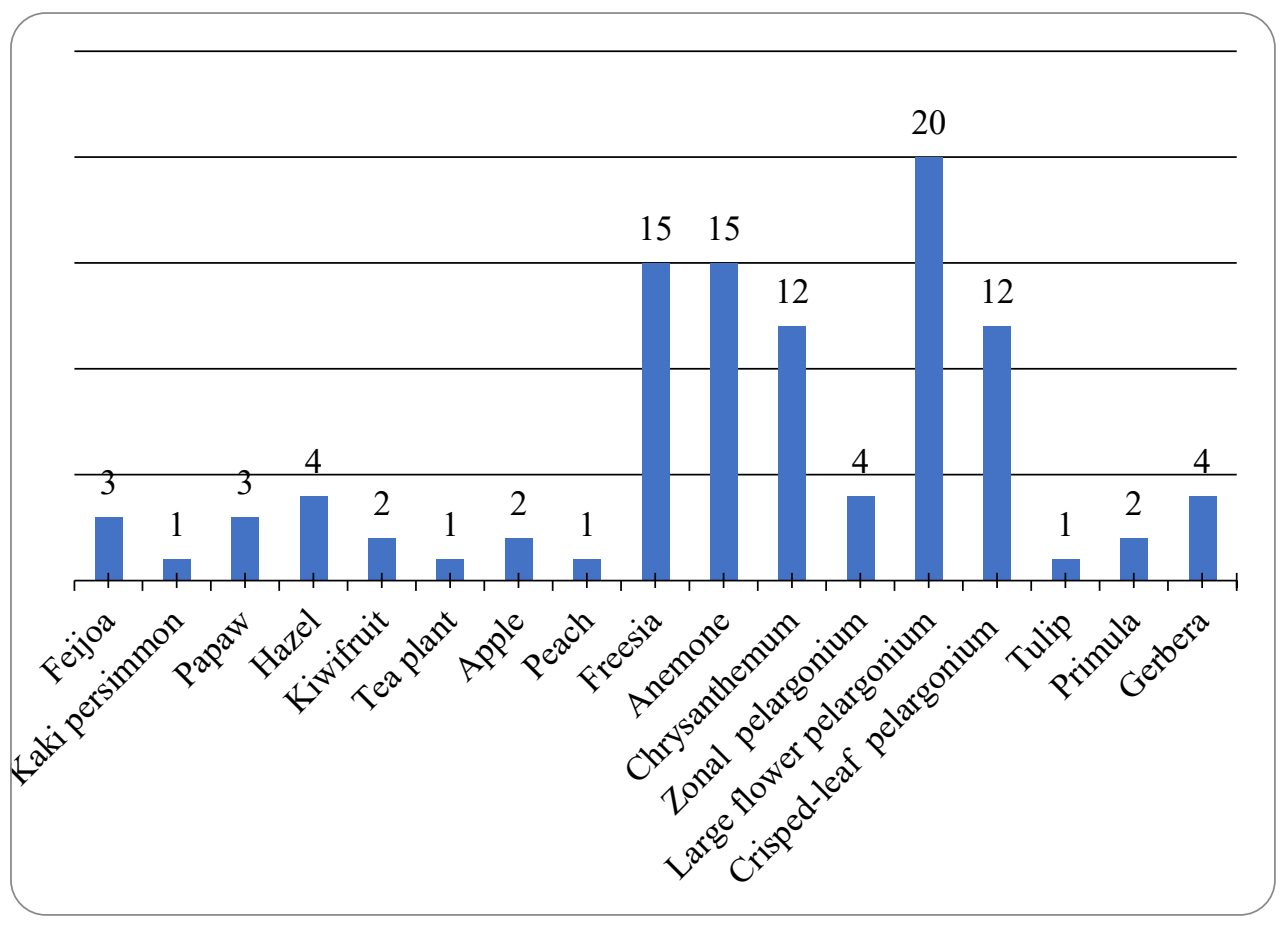

Fig. 2. Cultivars of FRC SSC of RAS included in the State Register of Selection Achievements of the Russian Federation from 2011 to 2021.

Feijoa cultivars 'Dachnaya', 'Dagomysskaya', 'Sentyabrskaya, which have high yields, resistance to diseases and pests, and different maturation periods, as well as kaki persimmon cultivar 'MVG Omarova' with high winter hardiness have been created for further expansion to more northern regions. Cultivars of the rare fruit crop called papaw, which have no analogues of cultivation, have been bred. The cultivars of thermophilic freesia created in the Centre are adapted to the extreme (for this crop) conditions in the humid subtropics of Russia, they are cultivated in indoor structures without additional heating. Resistant, highly decorative cultivars of crown anemone have been obtained for various uses, both for cutting and for use in landscaping. Pelargonium selection is carried out in the Centre with different sections of this genus and in different directions. Highly ornamental cultivars of large flower pelargonium bred by the Centre differ in various colours, in terms and duration of flowering, as well as in size of plants (from short to tall). Cultivars of crisped-leaf pelargonium are diverse in terms of growth strength, abundance and duration of flowering and aroma.

A special place in the Centre's research is occupied by the study of the collected species of natural flora, most of which have unique, including decorative, medicinal and other properties. More than $35 \%$ of the species have various rare statuses, 10 species are endemic, 15 are relict, 5 are both endemic and relict.

Thus, the genetic diversity of fruit, ornamental and wild-growing species concentrated in the FRC SSC of RAS is focused on the conservation and maintenance of biodiversity and creation of new resistant cultivars, as well as on the introduction and development of strategies for the conservation of unique, rare and endemic plant species. 
Acknowledgments. The publication was prepared within the framework of the implementation of the state assignment of FRC SSC of RAS No. 0492-2021-0008 "Creation, study and conservation of plant resource genetic collections of subtropical and ornamental crops" and No. 0492-2021-0009 "The study of mechanisms of significant traits inheritance and creation of new highly effective cultivars of subtropical and flower cultivars according to the complex of economically valuable traits".

\section{References}

1. Y. Kaipov, R. Akchurin, F.T. Shakirov, V.I. Shamsutdinov, J. Agric. Environ., 4(12) (2019) http://doi.org/10.23649/jae.2019.4.12.19

2. E.H. Mendybaev, S.G. Chekalin, G.S. Kaysagalieva, K.M. Ahmedenov, Bulletin of L.N. Gumilyov ENU, 4(129), 100-106 (2019) http://doi.org/10.32523/2616-6771-2019-1294-100-106

3. Y. Shirokov, V. Tikhnenko, E3S Web Conf., 273, 01025 (2021). http://doi.org/10.1051/e3sconf/202127301025

4. A. Kiselyov, M. Mayorova, N. Shishkina, M. Markin, E3S Web Conf., 291, 02015 (2021) http://doi.org/10.1051/e3sconf/202129102015

5. E.A. Egorov, L.L. Buntsevich, Horticulture and viticulture, 2, 39-42 (2018). http://doi.org/10.25556/VSTISP.2018.2.12305

6. R C. Gergerich, R.A. Welliver, S. Gettys, N.K. Osterbauer, S. Kamenidou, R.R. Martin, D.A. Golino, K. Eastwell, M. Fuchs, G. Vidalakis, I. E. Tzanetakis, Plant Dis., 99(2), 176-187 (2015) http://doi.org/10.1094/PDIS-07-14-0762-FE

7. K. Jindo, F.L. Olivares, D.J. da Paixão Malcher, M.A. Sanchez-Monedero, C. Kempenaar, L.P. Canellas, Front. Plant Sci., 11, $426 \quad$ (2020) http://doi.org/10.3389/fpls.2020.00426

8. F. Zulfiqar, A. Casadesús, H. Brockman, S. Munné-Bosch, Plant Sci., 295, 110194 (2020) http://doi.org/10.1016/j.plantsci.2019.110194

9. L. Ya. Ayba, N. N. Karpun, Ye. V. Mikhailova, G. G. Pantiya, IOP Conf. Ser.: Earth Environ. Sci., 604, 012019. (2020) http://doi.org/10.1088/1755-1315/604/1/012019

10. Ye. V. Mikhailova, N. N. Karpun, IOP Conf. Ser.: Earth Environ. Sci., 723, 022058 (2021) http://doi.org/10.1088/1755-1315/723/2/022058

11. G.H. Smith, J.M. Roberts, T.W. Pope, Crop Protect., 110, 125-130 (2018) http://doi.org/10.1016/j.cropro.2018.04.011

12. M. Ljubojevic, $\quad$ Sci. Hortic., $288, \quad 110350$ http://doi.org/10.1016/j.scienta.2021.110350

13. C.-R. Chang, M.-C. Chen, M.-H. Su, Landsc. Urban Plan., 208, 104023 (2021) http://doi.org/10.1016/j.landurbplan.2020.104023

14. A. V. Ryndin, R. V. Kulyan, N. A. Slepchenko, Vavilov J. of Genetics and Breeding, 25(4), 420-432 (2021) http://doi.org/10.18699/VJ21.047

15. A.V. Ryndin, R.V. Kulyan, N.A. Slepchenko, Ts.V. Tutberidze, V.M. Gorshkov, Subtropical and ornamental horticulture, 77, 25-43 (2021) http://doi.org/10.31360/22253068-2021-77-25-43

16. N. M. Gutiyeva, Atlas of large-flower pelargonium cultivars, promising for the subtropics of the Russian Federation, 100 (2020) ISBN 978-5-904533-37-3

17. M. D. Omarov, Z. M. Omarova, N. N. Karpun, Feijoa crop in the humid subtropics of Russia, 180 (2020) ISBN 978-5-904533-39-7 